\title{
Heidegger's Twofold Treatment of Modern Technology
}

\author{
TOMAS NEMUNAS MICKEVIČIUS \\ Vilnius University, Post-doctoral Fellow (Philosophy) \\ Email:nemunas.tomas@gmail.com
}

\begin{abstract}
In this article the twofoldness of Heidegger's treatment of modern technology is presented. Firstly, it is shown that one can trace the line of thinking on modern technology from the earliest to the latest of Heidegger's thinking periods. Though Heidegger claimed that it was firstly the task to understand the essence of modern technology that concerned him, it is still possible to discern basic trends of treatment or evaluation of modern technology in his thinking. On the one hand, the Heideggerian critique of modern technoscientific revelation of reality is presented: Heidegger stressed not only the negative practical consequences of technology as ecological crisis but also ontological ones as the disappearance of the experience of Being itself. The program of the overcoming of technology is presented as well as some examples of the alternatives. On the other hand, the positive or appropriative treatment of modern technology is presented. The fragmentary suggestions that it is precisely the modern technological revealing of reality that prepares the way for the authentic experience of Being are developed by connecting them with early Heidegger's claim that it is the basic experience of production that forms the conceptual horizon of Western culture. The possibility that this line of Heideggerian thinking might help to understand and articulate such important phenomena of current technoscientific condition as synthetic biology is mentioned.
\end{abstract}

Keywords: being, production, technology, technoscience, philosophy of technology, critique of technology

\section{INTRODUCTION}

Heidegger's own motto or epigraph to his Collected Writings (Gesamtausgabe) is "ways, not works" (Wege, nicht Werke). This expression signifies the fact that, according to the author himself, he did not leave us any finished or systematized collection of knowledge, but rather the attempts to think or hints (Winke) at possible directions of this endeavour. Scholars have noticed that these ways of thought often take different directions even while reflecting on the same subjects, and this sometimes happens to such a degree that these lines of thinking even contradict each other. This, without a doubt, also applies to Heidegger's thinking on modern technology. I differentiate two main Heidegger's strategies towards technology: the one that opposes it (the negative treatment) and the one that tries to appropriate it (the positive one). Heidegger himself claimed that it was an attempt to understand the essence of 
modern technology - not to evaluate it - that was the task of his thinking, but I think that we can still discern specific kinds of its treatment while analysing Heidegger's texts. But before explicating these two main strategies, I would like to present the centrality of the topic of technology in Heidegger's thought as a whole.

\section{THE CENTRALITY OF THE THEME OF TECHNOLOGY IN HEIDEGGER'S THINKING}

Phenomenon-wise Heidegger understands technology in a very broad fashion. In an article "Overcoming Metaphysics" from the thirties we read: "This name includes all the areas of beings $\langle\ldots\rangle$ : objectified nature, the business of culture, manufactured politics, and the gloss of ideals overlying everything" (Heidegger 2003: 93). In another article "Onto-theo-logical Constitution of Metaphysics" from the fifties it is still quite similarly described: "What now $i s$, is marked by the dominance of the active nature of modern technology. This dominance is already presenting itself in all areas of life, by various identifiable traits such as functionalization, systematic improvement, automation, bureaucratization, communications" (Heidegger 2002: 51-52). This motive was common among the Western intellectuals in times of development of industrial society. But there is also something quite unique in Heidegger's account of technology. The just mentioned phenomena and processes of the all-encompassing technologization actually are not what technology really is. According to Heidegger, the essence of technology is itself not technological, it is not the technical apparatuses and processes themselves. Technology is rather a particular opening or revealing of Being. Richard Rojcewicz even writes that, "<...> for Heidegger the philosophy of technology is actually equivalent to first philosophy, since, for him, technology is nothing other than the knowledge of what it means to be in general" (Rojcewicz 2006: 9). It is the question of Being (Seinsfrage) that is foremost important for Heidegger and technicity (or non-technicity) of Being is at least one of the main aspects of this thinking. In the text dedicated to the first Heidegger Circle gathering in Chicago in 1966 Heidegger wrote: “The "Being-Question", properly understood, appears as the question about the essencing of modern technicity and its relationship to the man of today, i.e., to an industrial society" (Richardson 1968: 18).

It is only the middle Heidegger that explicitly raises the question of modern technology, starting with Contributions to Philosophy (Beiträge zur Philosophie) and Mindfulness (Besinnung) of the thirties, but in a retrogressive fashion we could trace the implicit thread of this thought from the very early period of his thinking. Since at least the eighth decade of the last century the Heideggerian scholarship has tried to retrace the question of technology in Heidegger's magnum opus - Sein und Zeit. D. Ihde raised the question what is the relationship between the famous notion of Zeug or equipment in Being and Time and the later notion of the all-embracing opening of reality through the lens of Gestell as a standing reserve (Bestand) to be exploited by the machinery of modern technology (Ihde 2010 [1979]). Later there appeared other reasonable attempts to discuss the relationship between other concepts of Being and Time and later descriptions of modern technology, but the mentioned one is the most important, because Heidegger himself claims (Heidegger 1995: 117) that the notion of equipment is deeply connected with the structure of production.

Precisely the concept of production (Herstellung) is at the core of the attempts to seek the origins of the late Heidegger's conception of modern technology in an even earlier period of his thinking. M. Zimmermann already mentions the importance of Ancient Greek "productionist metaphysics" (Zimmermann 1990: 15) for the development of modern technology, but it is only recently that $\mathrm{H}$. Ruin $(2013,2014)$ explicates this line of thought in more 
detail: he argues for the possibility to trace the roots of conception of the essence of modern technology as Gestell in the conception of Hergestelltsein (Being-produced) explicated as early as 1922 in the so-called Natorp-Bericht (Heidegger 2005). According to these authors, early Heidegger's insistence that the Ancient Greeks understood Being through the basic model of production already implies the concern for the origins of modern technology.

It could be said that the line of thought on technology in Heidegger - which is very near to the story of his thought as a whole - could be expressed through these basic and intertwined concepts: being-produced (Hergestelltsein (to the range of this concept the work Being and Time belongs), machination (Machenschaft) ("machen" (making) is also connected with producing) and enframing (Gestell). The notion of production is at the core of all the periods of this thinking.

\section{THE SEARCH FOR ALTERNATIVES FOR THE DOMINION OF TECHNOLOGY}

After presenting the centrality of the topic of technology in Heidegger's thought as a whole, we can turn to one of the main strategies towards technology, namely, the negative one or the one that opposes the modern technological understanding of Being. As is well known, the essence of technology consists of Gestell as a combination of various modes of „stellen“ (placing): vorstellen (representing), herstellen (producing) and others. Its characteristic is that it does not let nature appear naturally, but rather it provokes (herausfordert) it to appear according to artificial requirements set by technology. According to Heidegger, this opening of Being is dangerous (Gefährlich). It is such, first of all, because of its evident potential and actual practical consequences as, for example, the extinction of life on Earth as a consequence of a global nuclear war, the unknown possibilities of biotechnological manipulation with the very core of life (especially human) or the degradation of nature as a consequence of the unceasing and ever-increasing process of production and consumption. Thus there appeared the attempts to find a theoretical grounding for ecological philosophy in Heidegger's writings (a comprehensive overview of the discussion can be found in the article of T. Glazebrook (2013)). But more important for Heidegger is the ontological dangerousness of technology: that this technological understanding of reality, while presenting itself as the only possible way of understanding of Being, might possibly eliminate any other forms of revealing of Being and the very fact that it is a revealing of Being. In other words, it poses a threat that Being itself might be forgotten. Though Heidegger did not offer any solutions to the mentioned practical dangers of the dominion of the technological (indeed, he was entirely sceptical about the possibility of rational and political human intervention into the dominion of the technological), he offered some alternatives for the latter in the ontological realm.

Here we have to understand Heidegger's notion of Überwindung or “overcoming”. As Heidegger argued that metaphysics has to be overcome, so has technology itself, which is nothing other than the very completion of metaphysics and metaphysical thinking, which started with the Ancient Greeks. In my opinion, to find a solution to the threat of technology, to overcome it, Heidegger offers at least few strategies. For example, we could start with a reflection on the thing (das Ding). According to Heidegger, the conceptual horizon of cause or causality (which itself arises from the mentioned basic experience of production) is one of the main aspects of technological understanding of Being and it is precisely the rejection of this conceptual horizon that starts his reflection on the thing (Heidegger 2012: 5). In the "Origin of the Work of Art", while also attempting to reflect on the thing itself, Heidegger disposes of the dominating conceptual pair of matter and form, which $\mathrm{H}$. Ruin characterizes as "a technologically oriented 
matrix" (Ruin 2013: 357) of understanding. So I understand Heidegger's invitation to reflect on the thing itself, for example, a jug, without the common notions of cause and form and matter, as an attempt to find some other way of experience than the dominating technological experience of reality.

The other motive of Heidegger's thought which is, in my opinion, dedicated to be an alternative for the dominating technological understanding of Being, is his notion of the Fourfold (das Geviert). It is actually deeply connected with the notion of the thing. Heidegger introduces this notion to rescue the experience of the thing from its being entangled in the technological patterns of production and consumption which became a substitute for natural interrelationships which constitute the natural experience of the world. To restore the primordial experience of the interrelationships of the world - which is constitutive for the original experience of the thing - Heidegger suggests a notion of Geviert, combining the structural elements of earth, sky, gods and mortals (Heidegger 2012: 11). This concrete place-oriented experience - elsewhere explicated as dwelling (wohnen) - should be opposed to the technological displacing interpretation of the thing as entangled in the meaningless world of obtaining resources, storing resources and then exploiting those resources in order to obtain even more resources.

Another motive, which Heidegger sometimes opposed to the technological understanding of reality, is Being itself. This reflection (which is sometimes named as the reflection on Lichtung or Ereignis) is counterposed to the classical thinking of the Being of beings which is, according to Heidegger, now taken over by technoscience (Heidegger 1972: 58). There could be added even more motives of Heideggerian thinking which could be considered as his attempts to overcome the dominion of the technological understanding of reality, but now it is sufficient to summarize that there is in Heidegger's corpus - especially in the middle of his career - a strong line of attempt to find an alternative for the all-encompassing technologization.

\section{THE ATTEMPT TO APPROPRIATE TECHNOLOGY}

Now we can turn to the second main strategy of Heidegger towards technology, namely, the appropriative or the positive one. This is mostly explicated in the thought of later Heidegger, starting perhaps with the Bremen Lectures from 1949. If before we had to talk about Überwindung, now we have to address the notion of Verwindung. Contrary to his previous claims, Heidegger now states that it is not possible for human being to overcome technology - it would mean, if we remember that technology is a way of Being itself, that human is the ruler of Being. So here Heidegger suggests that the dominion of technology cannot be denied, but rather it has to be accepted and one even has to immerse oneself into it. This is connected with Heidegger's interpretation of Friedrich Hölderlin's line "where the danger is, grows the saving power also" (Heidegger 1977: 28). In "Question Concerning Technology" he suggested that the now dominating technological understanding of Being is not only dangerous, but also contains within itself saving potencies. To this, I suppose, also corresponds Heidegger's notion of Ereignis. It is a mysterious and barely explicated Heidegger's suggestion that it is precisely the technological understanding of reality through the lens of Gestell that is a first glimpse of the authentic experience of Being itself. As we read in the "Principle of Identity": "What we experience in the frame as the constellation of Being and man through the modern world of technology is a prelude to what is called the event of appropriation" (Heidegger 2002: 36-37). As the concept Ereignis contains in itself a connotation of what is "own" ("eigen"), it 
might just appear that the later Heidegger invited us to make technologization our "own", to appropriate, to admit it, and see what comes out of it. Heidegger did not explicate in detail what he meant when talking about this saving power of technology, so this task is still open to be developed. As G. Vattimo observes, "Of course it is not easy to see what a verwindend recollection of the 'messages' of science and technology would be: the reconstruction perhaps of a Weltanschauung, of a unified view of the world, out of the manifold information provided by the natural and the human sciences" (Vattimo 1991: 178).

Let us read some other Heidegger's suggestions in this direction. In the article dedicated to the poet Johann Peter Hebel ("Hebel - Friend of the House") he wrote: "We are errant today in a world which is a house without a friend, that is, which lacks that house-friend who in equal manner and with equal force is inclined toward both the technologically constructed world-edifice and the world as the house for a more original dwelling. Missing is that friend of the house who is able to re-entrust the calculability and technology of nature to the open mystery of a newly experienced naturalness of nature" (Heidegger 1983: 98). Here (and in other similar hints as well), I think, Heidegger suggests to poetically ponder on the meaning of the newly revealed nature in the context of modern techno-scientific possibilities; not to deny the techno-scientific possibilities as an attack on nature - which was quite an option in the earlier Heidegger - but rather to reflect what this manipulability of nature through technoscience reveals us about nature. Another important fragment is from Bremen Lectures; there we read: "The essential genealogy of positionality [Gestell] as the essence of technology reaches into and shows the essential provenance of the Western-European and, today, plane-

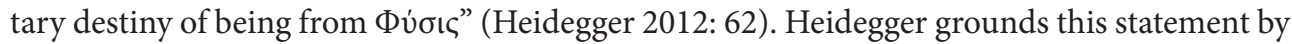
referring to "The $\Theta \dot{\varepsilon} \sigma \iota \varsigma$ concealed in the essence of $\Phi \dot{\sigma} \sigma \varsigma$ at the dawn of the destiny of being, i.e., positioning [Stellen] <...>" (Heidegger 2012: 62). Here also - quite contrary to his claims elsewhere - Heidegger does not oppose nature (and even Being itself) to technology, but rather inscribes the latter at the core of the former. Perhaps this statement could be connected with the mentioned notion of Hergestellsein - the claim that the Ancient Greeks understood nature and Being itself through the structure of the basic experience of producing an artifact. Maybe this conception of technology could shed light on such important phenomenon of the current technoscientific condition of culture as CRISPR genome editing technology which lets to modify the genetic core of organisms, that is, artificially control what previously used to be held to be completely natural and thus out of reach of human control. Maybe this could help to articulate the significant disappearance of the distinction between natural and artificial with the rise of synthetic biology ${ }^{1}$, which now attempts to produce life forms the so-called "living technologies" - artificially. In other words, maybe this currently arising technoscientific understanding of nature is not so new given early Heidegger's insistence that already the Ancient Greeks understood $\varphi v$ бıৎ through the structure of $\tau \dot{\varepsilon} \chi v \eta$. Though the later Heidegger presented his more positive evaluation of modern technology only in a fragmentary way, maybe it is possible to find a firmer ground in his early explication of the basic experience of production, which, according to him, formed the conceptual ground of Ancient Greek thinking, and which might help to articulate the currently becoming more and more dominating logic of producibility of reality.

1 Some work is already done in this direction by M. G. Weiss $(2011,2016)$ (who suggests the possibility to use Heidegger's notion of Herstellung to understand synthetic biology) and P. Schyfter (2012). 


\section{CONCLUSIONS}

The topic of modern technology is central to the whole of Heidegger's thought. Not only the late texts explicitly dedicated to the subject, but it could be also reasonably argued that even such texts as (a significant part of) Being and Time and even earlier, dedicated to explicate the experience of production as the ground of Ancient Greek thinking, implicitly shed light on the subject. Although Heidegger himself claimed that it is an attempt to understand the essence of modern technology that is the task of his thinking, it is also possible to discern the main lines of treatment of modern technology in it, namely, the negative one and the positive one. On the one hand, Heidegger criticizes such negative consequences of modern technology as ecological crisis and, more importantly, the disappearance of the experience of Being itself. Heidegger invited to overcome the technological understanding of reality and proposed such alternatives as the reflection on the thing itself and others. On the other hand, there exists in Heidegger's thought a less explicated positive evaluation of modern technology. According to this line of thinking, it is precisely the modern technoscientific view of reality that prepares the way for the authentic experience of Being itself. As this line of thinking is explicated only in a fragmentary fashion, it might be useful to connect it with early Heidegger's concern with the roots of Western culture, namely, the basic Ancient Greek experience of reality through the lens of producing an artifact. This could help to understand and articulate such important phenomena of the current technoscientific culture as disappearance of the distinction between the natural and the artificial with the help of synthetic biology.

\section{References}

1. Glazebrook, T. 2013. "Heidegger and Environmental Philosophy", in The Bloomsbury Companion to Heidegger, eds. F. Raffoul and E. S. Nelson. London, New Dehli, New York, Sydney: Bloomsbury, 433-440.

2. Heidegger, M. 1972. On Time and Being. New York, Hagerstown, San Francisco, London: Harper \& Row.

3. Heidegger, M. 1977. The Question Concerning Technology and Other Essays. New York and London: Garland Publishing.

4. Heidegger, M. 1983. "Hebel - Friend of the House", in Contemporary German Philosophy 3, eds. D. Christensen et al. Pennsylvania: Penn State University Press, 89-101.

5. Heidegger, M. 1995. Aristotle's Metaphysics $\Theta 1$ 1-3. On the Essence and Actuality of Force. Bloomington and Indianapolis: Indiana University Press.

6. Heidegger, M. 2002. Identity and Difference. Chicago: The University of Chicago Press.

7. Heidegger, M. 2003. The End of Philosophy. Chicago: The University of Chicago Press.

8. Heidegger, M. 2005. "Phänomenologische Interpretationen zu Aristoteles (Anzeige der hermeneutischen Situation)", in Phänomenologische Interpretationen ausgewählter Abhandlungen des Aristoteles zur Ontologie und Logik. Frankfurt am Main: Vittorio Klostermann, 345-396.

9. Heidegger, M. 2012. Freiburg and Bremen Lectures. Bloomington and Indianapolis: Indiana University Press.

10. Ihde, D. 2010. “Heidegger's Philosophy of Technology”, in Heidegger's Technologies. Postphenomenological Perspectives. New York: Fordham University Press, 28-55.

11. Richardson, W. J. 1968. "A Letter from Heidegger, with Commentary”, in Heidegger and the Quest for Truth, ed. M. S. Frings. Chicago: Quadrangle Books, 17-27.

12. Rojcewicz, R. 2006. The Gods and Technology. New York: New York University Press.

13. Ruin, H. 2013. "Technology”, in Bloomsbury Companion to Heidegger, eds. F. Raffoul and E. Nelson. London, New Dehli, New York, Sydney: Bloomsbury Academic, 353-359.

14. Ruin, H. 2014. "Ge-stell: Enframing as the Essence of Technology", in Martin Heidegger: Key Concepts, ed. B. Davis. New York: Routledge, 183-194.

15. Schyfter, P. 2012. "Standing Reserves of Function: A Heideggerian Reading of Synthetic Biology", Philosophy \& Technology 25(2): 199-219. 
16. Vattimo, G. 1991. The End of Modernity. Baltimore: The Johns Hopkins University Press.

17. Weiss, M. G. 2011. "Verstehen wir, was wir herstellen können? Martin Heidegger und die Synthetische Biologie", in Was ist Leben im Zeitalter seiner technischen Machbarkeit? Beiträge zur Ethik der Synthetischen Biologie, eds. P. Dabrock et al. München: Verlag Karl Alber, 173-193.

18. Weiss, M. G. 2016. "Epistemological Implications of Synthetic Biology: A Heideggerian Perspective", in Ethics of Science and Technology Assessment 45, eds. K. Hagen et al. Berlin, Heidelberg, New York: Springer, 325-335.

19. Zimmermann, M. 1990. Heidegger's Confrontation with Modernity: Technology, Politics, Art. Indiana: Indiana University Press.

TOMAS NEMUNAS MICKEVIČIUS

\title{
Dvilypė M. Heideggerio moderniosios technikos traktuotè
}

\begin{abstract}
Santrauka
Straipsnyje pristatomas M. Heideggerio tekstuose matomas moderniosios technikos traktavimo dvilypumas. Pirmiausia parodoma, kad moderniosios technikos apmąstymo giją galima atsekti nuo ankstyviausio iki vèlyviausio filosofo darbo periodų. Nors pats mąstytojas teigé, kad jam rūpejję suprasti moderniosios technikos esmę, vis dèlto jo apmąstymuose galima išskirti pagrindines technikos traktuotès ar vertinimo kryptis. Viena vertus, pristatoma heidegeriškoji moderniosios technomokslinès tikrovès atverties kritika: M. Heideggeris akcentavo ne tik tokius neigiamus praktinius moderniosios technikos padarinius kaip ekologinè krizè, bet ir ontologinius, pirmiausia - pačios būties ịžvalgos nykimą. Pristatoma technikos įveikos programa bei kelios alternatyvos techniniam santykiui su tikrove. Kita vertus, pristatoma pozityvioji ar įsisavinančioji moderniosios technikos traktuotė. Fragmentiškai pateiktos sugestijos, kad būtent modernioji technine tikrovès atvertis parengia kelią autentiškai būties patirčiai, išplètojamos remiantis ankstyvojo M. Heideggerio teigimu, kad Vakarų kultūros konceptualinị horizontą formuoja pamatine gaminimo patirtis. Užsimenama apie galimybę, kad ši heidegeriškojo mąstymo kryptis gali pagelbèti suprasti ir artikuliuoti tokius svarbius šiuolaikinès technomokslinès kultūros situacijos fenomenus kaip sintetinè biologija.
\end{abstract}

Raktažodžiai: būtis, gaminimas, technika, technomokslas, technikos filosofija, technikos kritika 